\title{
Spousal Secret Affairs with Money: Intra-household Allocative Efficiency in Spaces of Gender Politics in Development
}

\author{
Gamel Abdul-Nasser Salifu ${ }^{1}$ \\ ${ }^{1}$ Department of Economics, School of Liberal Arts and Social Sciences, (SOLASS), Ghana Institute of Management \\ and Public Administration, Achimota, Accra, Ghana
}

Correspendence: Alhaji Gamel Abdul-Nasser Salifu, Lecturer, Department of Economics, School of Liberal Arts and Social Sciences, Ghana Institute of Management and Public Administration, Achimota, Accra, Ghana.

Received: March 12, 2021

Accepted: April 15, 2021

Online Published: May 7, 2021

doi:10.5430/ijba.v12n3p108

URL: https://doi.org/10.5430/ijba.v12n3p108

\begin{abstract}
Persisting gender inequities across political, economic and social life have spurred the global agenda to re-examine the triggers and consequences of gender disaggregation in household resource allocations. Defining and measuring intrahousehold allocations has been at the centre of the current debates among international development scholars and practitioners. The lack of clear consensus on intrahousehold public good allocation has consistently limited widespread efforts to design and evaluate programmes and policies aimed at improving women's welfare. Based on intrahousehold allocation models, this paper proposes a conceptual framework which can accommodate the welfare of the household as an economic entreprise. Building on Sen (1989) and Kabeer (1999), this paper selectively reviews the abundant literature that offers insights into intra-household decision- making process and gender relations. The review illustrates the importance of intrahousehold allocations and describes a set of individual strategies that household agents use to by-pass intrahousehold negotiations and to secure private consumption. In many of the instances where inefficiencies have been identified in the data, a possible immediate cause is individual behaviour aimed at securing personal resources and consumption. Even, if they come, at the expense of total resources available to the household. Although, it need not be the case that such strategic behaviour are necessarily the source of inefficiencies, they may well be feeding the flames of suboptimality in household production entreprises. That said, the paper clearly iterates circumstances under which non-cooperative behaviour of spousal income hiding could be vital to circumventing social norms which undermine Pareto productive efficiency. The paper further highlights the role played by collective resistance of social forces to economic changes that threaten social norms and gender roles. The study pinpoints evidence of collaborative efforts to stop women from embracing new economic opportunities that overturn traditional roles. Investigating the role played by household structure in reaching Pareto optimality for inefficient rural households, the paper concludes that neither monogamous nor polygynous conjugal units attain higher margins of efficiency. Instead, household agents played dictator games in public good allocation and responded opportunistically to private choices and strategies which optimized secret consumption.
\end{abstract}

Keywords: gender conflicts, intrahousehold resource allocation, productive efficiency, secrecy, non-cooperation, private consumption, social norms

\section{Introducation}

Persisting gender inequities across political, economic and social life have spurred global agendas to re-examine the triggers and consequences of gender disaggregation in household resource allocation and efficiency. The structural model of intra-household allocation and production efficiency provides the most comprehensive approach for analyzing and articulating the mysteries and dilemmas of inefficient households (Salifu, 2021; Acosta, et.al., 2020; Baland, \& Ziparo, 2018; Strauss \& Thomas, 1995; Kabeer, 1999; Sen, 1989). This approach offers new insights into social understanding of spousal disagreements in household resource allocations. More importantly, it promises to answer the question of how the intergenerational power dynamics of prevailing social norms have conspired to deepen household production losses and inefficiencies (Salifu, 2020; Akresh, Chen, \& Moore, 2012). The stark consequencies imposed by these growing inefficiencies in household modelling, have threatened to dismantle the theory of the household as an efficient agent for economic and social development. A review of the empirical 
evidence of gender difference in resource allocation and public good provision clearly shows that economists have struggled to model household behaviour in Africa, Asia and Latin America. Thus, Policy scholars and reseachers have not succeeded in modelling optimum strategies for reaching Pareto optimality in the public welfare distribution game of development.

Consequently, the empirical underpinnings of intra-household research have clearly been less convincing on the demonstration of the unitary assumption of the household as a joint decision-maker in household production enterprising and consumption (Salifu, 2019; Udry, 1996). The unitary model portrays the household as single entity-reource- pooling- agent striving for production efficiency and consumption (Uberoi, 1994). However, a deeper analysis of the evidence indicates the assumption is baseless. The model fails to take into account the nuances and complexities of gendered power imbalances within the household structure (Bernhardt, Field, Pande \& Rigol, 2019). Therefore the unitary hypothesis of the household model as a collective resource- pooling agent is simply not adequate to penetrate the depths of household production inefficiencies, let alone uncover the mysteries and dilemmas of "resource mis-allocations" in the developing world.

There is simply more to this dimension of household analysis, prompting researchers to pursue a new path of collective household modelling, which eliminates to a large degree, the inefficiencies of the unitary assumption. It approaches the subject of inefficiencies from the collective bargaining approach (Castilla, 2015). Here, the household is visualized as a bargaining entity with capacity to negotiate a derivation of Pareto optimality in decision-making processes (Hanmer \& Klugman, 2016). It relies on the empirical assumption that negotiations ensure efficient public good allocation and equitable distribution of household resources (Hoff, Kshetramade, \& Fehr, 2011). But in reality, nothing could be further from the pragmatics of household bargaining and allocation efficiency in production and consumption. Indeed, the numerous empirical studies which have tested the assumptions of the bargaining model have clearly demonstrated that household agents have unequal powers in intrahousehold bargaining and allocations (Green, Wilke \& Cooper, 2020). Household agents who tended to command high bargaining power by virtue of their positions assume the lion's share of income allocations whiles less important members with low bargaining powers have no say. In clear terms, although the theory assumes agents to belong in the same boat, they are clearly unequal partners on the boat. Under this circumstance, Pareto efficiency which is the goal of intrahousehold resource allocation becomes quite an impossible objective to achieve in the developing world.

Udry (1996) shows that households in Bukina Faso do not reach Pareto efficiency because labour is not allocated optimally among plots of the same household. Dei Mei, Mckenzie and Woodruff (2009) detect productive inefficiency with experimental data in Kenya. They find that, women invest less than $40 \%$ of total proportion of cash grants they recieve into micro-entreprenuership, while men invest a little above $80 \%$ of grants on personal businesses. Consequently, men earned higher profits from microenterprises than women due to unequal access to factor endownments within the household structure. In designing policies to improve resource allocation efficiency of households, it is critical to evaluate the differences in access to productive resources and most importantly understand the strategies household agents use as response mechanisms to differentials in access to resources in the anthropological context of the household structure. This consideration is vital for two major reasons: First, it allows economists to forecast the impact of resource allocations on household welfare. Second, it helps to clarify the exact nature and effect of these differentials, illustrating why stresses in access to resources could contradict household efficiency in the first place and the measures to be undertaken to assure greater welfare outcomes in a sustainable manner.

Duflo and Udry (2004) evaluate the impact of resource allocation on household welfare in cote d' Ivoire. They find that households do not insure against transitory shocks which affect individual incomes hence production inefficiency is the norm. Dearcon and Krishna (2000) and Robinson (2012) reach similar conclusions in different contexts. Baland and Ziparo (2018) present a clear overview of the empirical regularities observed in the developing world that truly suggest that general theoretical framework to support household production efficiency is still lacking. They state categorically that non-cooperative behaviour of household agents agitates production inefficiencies. Angelluci and Galick (2016) support this conclusion attributing Latin America's household inefficiencies to non-cooperative behaviour in household decision making processes. They deploy experimental data to show that households do not reach pareto-efficiency in children's education and healthcare provision. They conclude that spousal strategic game playing to secure personal resources at the expense of the household is largely responsible for intrahousehold allocative inefficiencies (Jakiela \& Ozier, 2016). These findings demonstrate that only cooperative models in public good allocation treatments respond to Pareto-efficiency.

In the light of these challenges, the urgency to interfere with intra-household power imbalances in designing 
effective public policies for enhancing household welfare in the developing world has become imperative. In this regard, many economists have advocated for creation of new income flows towards vulnerable members of the household who have little bargaining power in household decision-making trajectories. This is viewed as a long-term strategy to improving household functioning as strategic income seeking behaviour of household agents imply suboptimal results for production efficiency.

This paper examines the social norms that ingrain non-cooperative behaviour of household agents and how they could be modified to achieve Pareto optimality in household public good allocation efforts. The paper seeks to define the set of roles which influence non-cooperative behaviour within the web of the social norms. As literature clearly points to gender roles assigned by the social norms of the household institution, household agents have specific duties to be performed. These duties define access and limitations to household resources. Household agents that are assigned leadership roles, have significant control and use of household resources. This leaves a margin of maneuvering for rent- seeking behaviour that could significantly undermine the overall household production objective of efficiency and optimality.

\subsection{Analytical Framework}

A systemtic review is inherently an important approach across different fields. It is a way of sieving large bodies of information to make sense, remove uncertainty and to offer high credence to research findings for the purpose of creating generalisations from resolution of controversies identified in the literature. The review applied an analytical framework based on three three themes: (a) Conceptual perspectives to a grounded understanding of pareto inefficient intrahousehold allocations in Africa, Asia and Latin America; (b) units of analysis focused on heterogeneity in the efficiency of intrahousehold resource allocation and discussion of data material on household bargaining, spousal control and feminisation of responsibilities; and (c) research methodologies.

These themes were identified in order to review the evolution and current status of conceptual perspectives and methodologies utilized for a thorough examination of intrahousehold public good allocation question in development economics. More importantly, it presented experimental evidence of how social norms define patterns of income allocations. With particular emphasis, on the power dimensions of allocations and a grand survey of the paradox of strategic behaviour of women, to keep secret kitties as a response to gender inequalities and asset ownership gaps. The study targeted economic science databases for the systemic review. It consulted databases which had a broad range of top tier journals related to intrahousehold allocation efficiency and gender relations in production themes. A range of peer-reviewed journal articles published over the last 100 years of development economics research and appeared in principal social science citations were selected for interogation. The review focused on the implications of these themes on public policy formulation.

\section{Household Functioning}

\subsection{Social Lineage Systems and Household Organisation}

To fully appreciate the socio-economic impact of household decision making on allocative efficiency of public goods, it is essential to define the context in which household business is conducted (LaFave, \& Thomas, 2017). Four major issues are critical in modelling household business as an organised unit. First, it is important to state that the nuclear household model which assumes joint decision making in resource allocation, is certainly inadequate a model to reveal the entire characteristics of the household structure within the anthropological context of social norms (Munro, 2018). Second, the household structure of the developing world has defied the empirical pooling assumptions of household models (Pecenka \& Kundhlande, 2013).

The reality is, household resources are not always pooled for productive enterprises. Resources are either hidden or under-declared by household agents hence efficient planning is thwarted by such acts of non-cooperation. Third, social norms codify the behaviour of household agents, allocating more control of resources to the household head and less control to junior members of the household (Rosenzweig, \& Wolpin, 1985). Consequently, Men and Women have clearly defined levels of control of household resources based on specific duties to be performed by marital partners (Speizer, Lance, Verma, \& Benson, 2015). Couples may occasionally switch roles in the unlikely event of partner's incapacitation but nevertheless gender roles in developing world are codified by social norms.

These social norms are severely threatened when economic changes depict new roles for partners (Antman, 2018). Finally, to enhance Pareto efficiency in household production systems, it is important to state that codified social norms are influenced by absence of formal markets and public safety nets through social protection programmes (Beaman \& Dillon, 2012). Paulme (1960) presents a thorough description of the roles of spouses based on codified norms of society. He argues that men and women brought together by the institution of marriage are faced with the 
utter responsibility of honouring interests of their original lineages as well as being loyal to the interest of their spouses's lineage.

This places a huge burden on marital couples who are afraid to violate the sanctity and provisions of marital norms. Stiffer sanctions are stipulated for couples that infringe social norms. For instance, 'violating widows' may be disregarded by spousal lineage in inheritance of household resources including children (D'cruz \& Bharat, 2001). That said, the decision on ownership of children by the marital couple depends on the prevailing dominant lineage in the society. In matrilineal societies, where maternal lineage dominates the social inheritance systems, children belong to the matrilineal ancestory (Kambhampati \& Rajan, 2008).

The reverse is true for patriarchal societies where father's lineage dominates the inheritance systems and bears the right to child ownership (Bharat, 1994). Comparing these two lineages in African social systems, the findings reveal that maternal societies foster less interests in conjugal relationships hence have the potential to generate intra-household conflicts due to the divergent interest of the mother and children on one side and the father on the otherhand (Bobonis, 2009). Patriarchal societies on the other hand are destined to enforce conjugal commitments and foster conjugal links due to well aligned inheritance interests of couples (Caldwell, Reddy, \& Caldwell 1984).

The only disdvantage with the patrilineal system is that women appear rather weak in household bargaining and politics. Women are further mellowed by the enduring risk of losing entitlements to resources in an open resistance to the patrichal bargains. Wives in this system, have special need for social protection in their bargain for greater access to household resources. According to Munachonga (1988), the tension between husbands and wives in this system creates divergence of interest and a recipe for non-co-operation and disaggregation.

Recent gender studies on household bargaining and allocative efficiency suggest that social lineages and inheritance systems are largely responsible for the gender disparities and conflicts in intrahousehold resource allocation between husbands and wives. The work of Clark (1995) exemplifies the constraints faced by husbands in intrahousehold resource allocation under the matrilineal lineage system of the Asantes, the Porcupine Warriors in southern Ghana. In a separate account of gender roles under social lineages of West Africa, Falen (2011) provides a vivid account of the greater privileges accorded husbands under the patrilineal lineage systems of the Fon in Western Benin and the "Lion Warriors" of Dagomba in Northern Ghana. Under the different lineage systems, different privileges are accorded both partners. Greater concessions and economic autonomy are granted women in the Asante martrilineal lineages whereas the partrilineal lineages of the Dagomba and Fon accord greater privileges and entilements to men. It is better to be a woman in matrilineal clans. Consequently women are supposedly happier in the matrilineal systems whiles men enjoy their "lordship roles" under the patrilineal arrangements.

The evidence of Clark (1995) suggests that under the matrilineal system of the Asante society in Kumasi, the husband caters to the living expenses of the wife and children by providing periodical allowances to the family called 'chop money'. The husband also affords the wife greater social autonomy by allowing the wife to live separately from the family. Men support their wives to become economically vibrant by giving them the privilege to engage in any economic activity of their choice. This is seen as one of the greatest advantages of wives under the matrilineal conjugal arrangements. This certainly saves women the trouble of accounting to the husbands over use of her time and resources. With the partrilineal conjugal systems that command spouses to live together under the same roof, quarrels often ensue over use of wives' time and resources. Under the matrilineal arrangements, ignorance of the full extend of wive's income, makes husbands more positively disposed to taking on greater financial cost of the conjugal relationship than would likely be the case in patrilineal lineages. In the patriarchal societies of Fon and the Dagomba for instance, payment of the bridewealth gives husbands absolute control of the wife's economic and social activities.

The wife's use of her sexuality, time and labour are under the direct supervision and lordship of the husband and women are expected to comply if they intend to uphold the conjugal linkage (Chiappori, 1992). Marriage under the partrilineal lineage comes with greater economic and social costs to husbands as men are obligated to do more than provide daily 'chop money' (Cochard, Couprie, \& Hopfensitz, 2016). They are required to provide start-up capital for any economic activity of the woman's choice. This attribute is considered positive because the lineage of wives concur that good husbands do not shirk manly responsibilities towards wives (Heath, Hidrobo \& Roy, 2020).

Although gender roles under both lineal lineal systems appear rigid, occassionally household shocks and stresses dictate different roles for men and women. Bikketi et al. (2016) points out that in Kenya, although social norms and gendered expectations define the rules of conjugal engagements, spouses generally diverge from their traditional roles. This finding is corroborated by Hoodfar (1988) who asserts that in Egypt, the traditional expectation of women to remain as household wives is gradually being eroded as the necessity for increasing household earnings increase. He accounts that those women who were not permitted to work or manage household expenditure without husband's 
supervision, do so freely now. Maboudou and Niehof (2020) also find that as male earnings drop due to structural unemployment, women incomes are expected to act as shock absorbers in times of hardships. Under the two social lineages, greater freedom and economic autonomy is provided to women who are viewed as breadwinners and need to take up full-time jobs to earn incomes for family.

\subsection{Differential Access to Productive Assets and Income Earning Opportunities}

Gender disparities, control and ownership of assets are significant areas of interest in the discussion of intrahousehold resource allocation (Harris-Fry, Shrestha, Costello \& Saville, 2017). This is vital as empirical studies find scores of women experiencing marginal access to productive capital inputs and income earning opportunities in agricultural production systems. The study by Doss, Kovarik, Peterman, Quisumbing and van den Bold (2015), reveal that men have far greater control of productive assets and household factor endownments. Men's access to land for crop production far exceeds that of women. Infact, on the average men own 25 times as much land area for crop cultivation than women in Nigeria. Similar conclusions are drawn on asset ownership in other African countries such as Ethiopia, Malawi, Uganda and Niger.

The wide heterogeinity in asset ownership recorded by Doss, Deree, Oduro, and Swaminathan (2012) mirror similar conclusions in Asia and the Americas. Peterman, Behrman and Quisumbing (2011), find differential access to productive assets with women highly disadvantaged in access to technology and agricultural inputs. They conclude that due to these differences in access to vital inputs and extension servivices, women fail to reach technical efficiency in agricultural production. Hence, women's choice of crops with little fertilizer requirements is motivated by this stark reality. Although analysis of differential access to input defines agricultural productivity in the developing world, a thorough assessment of this vital perspective is conspicuously obscured by the extreme focus of gender studies on differential treatments of women to agricultural inputs using comparative approaches. This approach tends to draw conclusion on differential access based on comparison of female-headed households with male headed-households whiles neglecting the intrahousehold dynamics of resource allocations. However, within-household assessments discussed here find that women exercise little control over productive inputs due to low bargaining power on related matters of production and expropriation of their labour products.

The pioneering study of Boserup (1970) on household labour expropriations argues that although women in West Africa play a fundamental role in agriculture their contribution to household work is vastly underrated and not statistically well represented. Bikketi et al. (2016), confirms the underestimation of women's contribution to household work in rural Kenya pointing out that although women contributed significantly to household production, they still did not exercise full control of use of household assets even if they purchased them with their own income. The society still regarded the husband as owner of those assets and controlled the use and sale of produce from women's economic activities (Hidrobo, Hoel \& Wilson, 2020).

Women seem to lack the bargaining power to question this control over the use of resources and products of their work. In certain parts of Africa, where women exercise control of use of household resources, it is often associated with a huge social responsibility such as care of the living expenses of children in the absence of husbands (Iversen, Jackson, Kebede, Munro, \& Verschoor, 2011). The matrilineal lineage of the Asantes exemplifies this custom of increased responsibilities of women and their role in ensuring household stability and organisation for production efficiency. As earlier indicated by Clark (1995), the very active women traders of Kumasi are busy and participate fully in income- generation activities for promotion of household welfare. In the matrilineal lineage of the southeastern Asian clans, women have demonstrated this active income-earning potential through their control of fish transformation activities and trade (Niehof, 2007). However, under the patrilineal lineages, women are considered the weaker sex, and trading for income generation is not encouraged. Husbands looked upon their women participation in income generation activities as comprising their dignity. The prevailing norms have continued to limit women's full partipication in economic activities which generate household income.

Maher (1981) gives a vivid account of the social norm of Berber-speaking tribes of Morrocco, which bars women from active participation in income generation activities and sale of their labour. Women were confined to activities which prohibited direct interaction with strangers and contact with money. Even when women made money through buying and selling, husbands had full control of the proceeds of their business and labour. This theory is confirmed by Rashid (2013) who reports that married women in Bangledesh have no control over their income earnings and wages. In the garment industry of Bangledesh married women handed over their salary to their husbands and had no control over the use of their wages. The study reports that good husbands asserted their authority by not touching their wive's pay and therefore still underestimated women's role in household economy. 


\section{Economic Activities of the Household}

The economic activities that household members participate in are preordained by the prevailing social norms and organisation within the household (Jeffery \& Jeffery, 2018). Prevailing social norms therefore interfer with the private consumption privileges made possible by unlimited economic participation. If members feel limited in the private consumption opportunities that participation brings, they bypass the constraints to secretly or privately earn income to enjoy consumption. This secret practice has tremendous cost implications for household organisation and efficiency. In that, the overt mechanisms of secret kitties violate cooperative behaviour and therefore foster productive inefficiencies (Khatri, 1975). It is important to emphasise that although such non-cooperative permits financial privacy, it is done at the expense of household welfare. This does not augur well for productive efficiency because individual needs override household gains.

\subsection{Productive Inefficiencies}

Many empirical works conclude that non-cooperative behaviour has negative impact on intrahousehold allocations which increase production efficiencies in agricultural production systems. A study by Udry (1995) for instance, points to evidence of productive inefficiency in Burkina Faso, where female farms are under-supplied with capital inputs required for increasing agricultural output. The study approximates a $7 \%$ lose of agricultural output due to inefficient intrahousehold allocation of farm inputs such as fertilizer and labour supply. This suggests that productive efficiency would improve only when female-plots receive adequate input allocation. Despite the growing loss of agricultural output and productivity, husbands and wives still remain non-cooperative, unwilling to negotiate better resource allocation deals which will achieve Pareto optimal results on household-plots.

It is arguably noted in the gender literature that women non-cooperative behaviour and unwillingness to allow husbands to control their farms is informed by their fear of losing usufruct. However, it is not clear why husbands and wives would resist cooperative behaviour that would ultimately improve intrahousehold factor allocation which would improve productive efficiency. Several empirical studies have investigated reasons for continued engagement in non-cooperative behaviour which leads to productive inefficiency. Goldstein and Udry (2008), find that women in Ghana engage in non-cooperative strategies due to fear of loss of investments in land tenure agreements. Haider et.al (2018) confirms that behaviour is deliberate as it helps women to exercise absolute control of their investments in land tenure.

Although the evidence points to inefficiencies as a consequence of non-cooperative behaviour, women argue that given the limitations imposed by social norms which give husbands full control of their resources, engaging in this behaviour helps to secure individual incomes and wellbeing. This behaviour is not likely to abate as prevailing social norms continue to influence household resource allocations. Of the many studies that have ventured into the reasons for non-cooperative behaviour, few studies have actually identified the exact role of conscious choice to engage in non-cooperative behaviour to secure resources for private consumption. Therefore much as norms can constrain individual choices within the household, they also guide the set of acceptable behaviour patterns. In the face of growing evidence of intrahousehold resource allocation and efficiency, the best household strategy to enhance Pareto efficiency is to engage in strategies that are sensitive to the prevailing economic conditions of the general social environment (Voss, 2005). As economic circumstances evolve faster than norms it is expected that the friction between them would delicately be balanced to enhance economic welfare.

\subsection{Household Norms and Economic Shocks}

The friction between household norms and economic adaptations is illustrated in the growing impact of external economic shocks on household structure and organisation. As economic shocks alter resources and income flow dynamics of households, households are pushed to modify behaviour which enhances economic wellbeing and survival. Basset (2002) illustrates this household transition from indigenous farming systems to commercial farming systems following the introduction of cotton as cash crop in cote d'Ivorie. He relates that prior to the introduction, few households cultivated cotton and women were confined to peanuts and rice production. Women were required by the social norms to seek husband approval for children to work on their fields.

When cotton was introduced as cash crop, women did not seek their husband's approval to engage in this profitable agricultural venture. They competed with husbands for their share of new profits in cash crop production. Two major reasons were given for the displeasure of husbands regarding wives entry into cotton production. First, the adoption of cotton production surely jeopardized husband's control of wive's labour as women were required to follow the strict agricultural calendar of cotton production. Second, men were threatened by the increasing bargaining power of women that association with cash crops brought. Depending on the standing of women, wives had better access to 
extension, inputs and markets that cotton companies freely provided under outgrower scheme arrangements. Women with higher income had less difficulty securing external male labour to work on their fields if children were not permitted to work on their plots by their fathers.

These new developments compromised husbands' social and economic autonomy over their wives. In a different context where men participated less in rice production, Carney (2004) investigated the impact of new land allocation rights to rice farmers and gender conflicts in the Gambian wetlands. Traditionally the wetlands were devoted to rice production whiles uplands were used for cash crop production. Prior to the introduction of the allocation rights, women dominated the wetland rice production entreprises whiles men were focused on cash production on the upland fields. All that was about to change, when government suddenly introduced irrigation projects and improved seeds to aid rice output for improving food security in the Gambia. Husbands wanted a defacto change of places from uplands to wetlands. Women resisted the move to relocate and asked for more autonomy to keep their allotted lands and additional compensation for extra hours on husband fields.

Bruce (1998) gives another elaborate account of a similar development in Kenya, wherein moves to displace women from farms lands, resulted in negative nutritional outcomes for households. Infants starved from under-nutrition due to loss of women income and contribution to the household economy. Not only this, the move had other negatives impacts on marital trajectories and wellbeing. It created domestic tensions and less cooperation between household agents. Few studies have been this explicit about the association between women income reduction and nutritional wellbeing of children. Jones (1983) investigates the household decision factors associated with women income erosion. She finds that women labour on husband's fields is grossly under-compensated while's woefully worsening household nutrition and child care. She estimates that the opportunity for joint labour is high for married women who do not control the product of their labour. The empirical works cited here show that household members engage in non-cooperative strategies in order to secure private consumption at the expense of household efficiency.

\subsection{Non-cooperative Strategies in the Household Production Game}

Several studies have investigated the driving the motives for non-cooperative behaviour in household production strategies. A discussion of the data material points to high margins of production inefficiencies in household production enterprises. The literature assigns two major reasons for low margins of efficiencies in the structural modelling of Pareto optimality in gendered production systems of agriculture; First, studies attribute the failure to reach climaxing levels of efficiency as the sole outcome of weak-altruism. In explaining the impact of altruism on production efficiency, Barr, Dekker, Janssen, Kebede and Kramer (2019) experiment with data in Southern Nigeria where polygamy is common. They compared spousal altruism in both monogamous and polygamous households. They discovered that altruism was relatively weaker in polygamous conjugal settings than in monogamous organisations. They concluded that monogamous households reached higher margins of production efficiencies than conjugal units of polygamous descent.

This theory is sharply debunked by Udry, Akresh, Chen and Moore (2016), who argue that strong altruism of monogamous households deters cooperation since household members refrain from retaliation in the event of deviation from the norm. Munruo, Kebede, Tarazona, and Verschoor (2019), have more to say on comparison of altruism in the two different household structures. Their evidence reject efficiency in both types of households and find no penalty with altruism in polygamous household settings. They insist polygynous households have an urge over monogamous households in resource pooling and mobilsation for production. The conclusions reached by the aforementioned studies indicate that the experimental evidence of the role of altruism in household cooperation and efficiency is still far from definitive. The existing evidence does not allow us to draw conclusions about the role played by altruism. The dynamic differences between monogamous and polygamous households are only based on resource games played by husbands and wives in which inefficient strategies lead to inefficient outcomes. Thus a husband does what is best for him, a wife does what is best for her, and somehow they all end up in poverty, which is not good for either.

Second possible explanation for use of non-cooperative strategies, is information assymetries. Guirkinger, Platteau, Goetgherbuer (2015), examined the effect of information assymetries on labour productivity in Mali. They compared labour productivity between collective plots supervised by the household head and individual plots farmed by junior male members of the household. The study finds that productivity is lower in collective fields compared to individual fields. This showed that household heads faced difficulties in securing high productivity from junior members of the household. The reason for non-cooperative behaviour of junior members in collective fields is due to rent-seeking behaviour, common among household heads. In collective fields, household heads commandeer the lion's share of output before junior members are considered in the harvest allocations. This model shows that junior male members 
provide little effort on common plots to preserve energy for individual fields which yield higher personal incomes.

\subsection{Consequence of Spousal Non-cooperative Strategies}

The discussions above allude to evidence of non-cooperative behaviour in production. Nonetheless, if household agents perceive a fundamental threat to their private consumption or a change in their personal circumstances, they opt for non-cooperation. This way personal private consumption is assured. Eventhough personal strategies run counter to social and economic changes, rational individuals resist changes that threaten gender status and roles within the household. Bassett (2002), provides evidence of household strategies which fuel gender conflicts and spousal disagreements in production and asset ownership. The study renders the resistance of husbands to social and economic changes in Cote d' Ivoire that favoured unlimited participation of women in cotton production. The evidence showed that women who adopted cotton faced difficulties in accessing inputs and needed husbands to help market their production.

The study documents an unfortunate incident in the market in which a man brought his wife's cotton to be processed for sale and was subsequently refused help by his fellow men to offload the cotton for weighing. He reports that a group of men protested against the husbands' action to market his wife's production in a male dominated entreprise. These protesting men said their wives were not growing cotton and would not permit the man to off load his wife's cotton for weighing. The treatment the husband received at the hands of his own peers demoralized husbands who sought to help market women produce. The group of men who felt threatened by progressive gender roles in the household chose to shame the man who was accepting the evolution of social norms to support the financial independence of women.

This position left progressive men in awkward situation. For the market scene had halted cash crop adoption and income changes within the household. The progressive men were not willing to be ostracized for aiding wives but women needed their cooperation for escaping the deprivation traps which genderised poverty. The literature shows that although cotton had been widely adopted by 1988, almost all women discontinued cotton production by 1994 . The obstruction implemented by the protesting men at the market scene was successful at maintaining the status quo in the Cote d' Ivoire. However, the consequence of the collective action of men triggered non-cooperative behaviour within the household. Women refused to harvest their husbands' cotton and showed less interest in having sexual relations (Sharma, 1980).

\subsection{Time as Constrained Resource}

Women access to economic opportunities and control of household resources remains a topical issue of concern in the discussion of intrahousehold resource allocation. Time as a vital resource of the household production is seen to task more women than men in agricultural production systems (See for the works of Hererra \& Torelli, 2003; Bardasi \& Wodon, 2006; Wodon \& Ying, 2010; Robles, 2010). These studies exemplify the classical cases of time constraints for women in their contribution to the household economy. These studies typicalize classical cases of prevailing social norms which assign most of the domestic and welfare responsibilities to women, who have increasing work load outside the household jurisdiction as breadwiners. This certainly places greater strain on women's time. As time becomes a scarce resource for women, they engage less in profitable businesses that accrue greater compensation and consumption rights.

Women are therefore time poor and would only overcome this barrier if they undertake strategic bargaining for more time allocation to work for higher personal incomes. Women need to bargain with men to take up some domestic responsibilities in order to secure time for professional roles outside the household duties. Jacquemin, Moguerou, Diop and Fatou (2018) document the experience of women in Dakar bargaining for time to secure incomes outside the household structure. The study interviewed married women with children under care from the working class to upper class. The interviews reveal that working wives assume heavy workload responsibilities in the household, exerting over 15 hours a day to domestic and professional entreprises. Women are able to free up time for professional work only by delegating domestic and welfare chores to foster young girls from the village. This strategy induces complex negotiations with husbands on which types of domestic chores they can delegate (Dhanaraj \& Mahambare, 2019). In these negotiations, husbands incur no additional cost for hired domestic labour and prefer wives to be solely devoted to them. In otherwords, domestic responsibilities directly related to the personal care of the husband such as food preparation and intimacy are not likely to be outsourced due to the close link between meal preparation and sex. These chores can hardly be delegated to foster girls.

This description of non-delegation of cooking chores echoes the findings of Hanrahan (2015) in Konkomba communities of Ghana. In this culture, cooking for the husband is the most sacred part of the marriage and cannot be 
outsourced to unknown foster young girls. Women are required to earn respect by distinguishing themselves in food preparation; a rare status which fully marks the acceptance of the newly married woman into the family fold. The evidence shows that, eventually women bear the social cost of circumventing the social norm of gaining time to earn extra income to support the household. In an aforementioned study, Clark (1995) points out that even under the matrilineal lineages where women are at liberty to use personal time to earn incomes; their economic success depends on their managerial ability to juggle simultaneously the competing demands for husband's care and labour time. Although, complete disengagement from domestic chores improves women business success outside the household, the fact remains that social norms require that women be devoted to household duties permitted by the husband.

\section{Savings and Hidden Income}

The evidence of spousal control of intrahousehold public good allocation reveals that gender status is only as sacred as the responsibilities that marital agents assume in the household. Heterosexual spousal responsibilities are closely allied with income and earning capacity of couples (Scott \& Karberg, 2016). Financial responsibilities of the household are often shifted to the well-to-do partner in conjugal arrangements. For this reason, marital agents play a game in which they use overt strategies to hide incomes and savings. Hiding income and savings from partners are strategies used to reach optimal positions in household politics.Under the penalty of secret affairs with money, conjugal agents' secure personal resources for private consumption; fending off spousal claims and limiting predation from other members of the household.

\subsection{Survey Evidence of Information Asymmetries}

A review of the experimental evidence of income hiding behaviour shows that household agents keep how much they earn a secret (Rossi, 2019). Marital agents fail to divulge real earnings in order to have greater discretionary powers about how much money they share with members of the household. Economists document instances of information asymmetries in household economy. They allude to evidence of high degree of spousal misinformation regarding real incomes, earnings and profits. This confirms the idea that spouses covert secret seperate accounts in order to secure private consumption. Ziparo (2014) investigates spousal income secrecy in Cameroon using structural questinnaires to capture knowledge of spouse's income in separate interviews. The study showed that slightly over $70 \%$ of the spouses interviewed declared little knowledge of partner's income. Those who confidently declared actual knowledge of spouse's income were off by at least $50 \%$. This means that on average spouses who attempt to estimate actual incomes of spouses tend to underestimate it by at least 50\%. Similar conclusion is reached by Fapohuda (1988), who investigated the secret financial affairs of conjugal households among the Yoruba in southern belt of Nigeria. The study revealed that more than $80 \%$ of wives had no knowledge of husband's income or their spouses' expenditure. Chen and Collins (2014) also show that husbands and wives under-reported their profits by at least 10 percent when their spouse is present during interviews.

\subsection{Sociological Evidence of Hiding Behaviour}

The sociological evidence of women's secret kitties is elaborated by Hoodfar (1998) who argues that women engage in the secret financial affairs to limit the financial responsibilities passed onto them by men. He reported that this personal secrecy on the part of wives was well justified by the fact that husbands tended to keep their own earnings for private consumption whiles tapping into the woman's savings for payment of collective family needs. Women wanted to protect themselves against changes in their financial and personal circumstances. The study showed that husbands responded to this secrecy by seeking to debar women from working if they were to spend earnings on themselves without allowing men to exercise some control over their earnings.

This situation is sharply at variance with the patriarchal norm of the Dagomba in Ghana and the Fon society of Benin. Husbands are supposed to give periodical allowances to women especially on market days to purchase entire family needs. Women use this opportunity to discretely pocket some of the allowance by haggling efficiently to make cheaper purchases (Falen, 2011). These pocketed allowances are used to ease off the burden of food provision for the entire household. Other strategies have been used elsewhere by women to hide income. Maher (1981) studied income hiding behaviour of women in Morrocco. His work uncovered food stuff hiding behaviour in Berber households. Wives gain control of some extra money for personal use by asking husbands for more housekeeping money to buy food. Lecarme-Frassy (2000) identifies male strategies used in Senegal to reduce wives' allowances. Husbands vary the daily allowances paid to wives to avoid any habit formations or purchase directly from the shop keeper. 


\subsection{Experimental Evidence of Hiding Behaviour}

The overt mechanisms of spousal secret kitties in intrahousehold allocations do not neccessarily lead to inefficiencies. On the contrary income hiding behaviour could improve personal consumption and welfare of women (Mani, 2020). The major problem with information asymmetries is that, the poor knowledge that marital agents display about each other's income certainly evidences non-cooperative bargains in intrahousehold resource allocation. Many experiments conducted to quantify the effect of non-cooperative bargains on household efficiency, have concluded that marital agents are willing to pay to hide information on secret savings for private consumption.

Ashraf (2009) examined the causal effects of secrecy on savings and consumption choices of couples in the Phillipines. Her assessment revealed that inefficiencies were explicitly tied to specific channels of incentives for income hiding. In her experimental setting, each partner received a windfall of income, that they chose either to use for their own consumption or saved in their own accounts, spouses account or joint account. The study found that both men and women allocated more money to their own account when the observability of the financial choices by the partner was reduced. Inefficiency was clearly demonstrated as subjects were willing to pay more to deposit money into own accounts.

Castilla and Walker (2013), studies the implication of information asymmetries on resource sharing among cohabiting spouses in southern Ghana. The experiment provides evidence of noncooperative behaviour as authors find a differential effect of private and public cash prizes on expenses. Pouliquen (2019), quantifies the willingness to pay to hide income in a specific context of Benin. He asseses whether formalization affects the propensity of spouses to hide a cash grant or otherwise. The study showed that spouses preferred less formalization of cash grants.

\subsection{Evidence of Savings}

Empirical studies of intrahoushold bargaining power demonstrate that conjugal agents adopt income hidding behaviour as a strategy to accumulate savings for investment into private business entreprises. The economic literature on household analysis shows that income hidding behaviour is necessitated by a sole desire to climb out of poverty. Pouliquen (2019) and Boltz et al. (2019), use experimented data to proof that income hiding behaviour could be closely associated with poverty reduction, savings and investment strategies of women. As long as hiding behaviour does not incur predatory consequences of partners, income secrecy could be more helpful to vulnerable household members than often accredited. Nonetheless, savings in secrecy might be the best option, if this practice is made difficult by predatory behaviour of spouses.

Eroglu (2009), points out that women overcome spousal predation by keeping secret caches whiles consolidating gains made on money diverted from household resources. Although, several authors have described in detail the income hiding behaviour of household agents, few studies have offered insights into strategies used by women to evade other family pressures to spend hidden income. Anderson and Baland (2002), report that women, escape the pressures of expenditure through channeling income in rotating savings and credit associations (Roscas). Given that savings through Roscas are time costly, women prefer this strategy when they are willing to accumulate income over time to buy a good. Women with intermediate bargaining power adopt this strategy to circumvent the fear of expropriation of their nest egg of savings.

\subsection{Consequencies of Savings}

The most devastating consequence of income hidding behaviour is revealed in the failure of the household to reach efficiency in production. The study assesses whether information asymmetries are a driver of non-efficient labour provision in rural Africa. As the study points out, although information asymmetries reduce efficiency of the household, household agents are willing to pay the price of engaging in this non-cooperative behaviour. Consequently, the cost of secrecy in intrahousehold resource allocation could be high for vulnerable households as evidence points to increasing cases of spousal disagreeements and gender conflicts in the household. Inevitably, this study finds it misleading to infer household inefficiencies from the relationship between inefficiency and secrecy. This is because empirical studies that have identified this relationship have done so using average treatment experiments. However, allowing for heterogeneities in the household responses to information asymmetries could improve the reliability of these treatments. For instance, Hoel (2015) examined household inefficiencies in Kenyan context in which individuals in a monogamous conjugal unit, played public good and dictator games in resource allocation. Each partner knew about the other's personal choices yet played out a private game where partners decision's were unknown to each other. The results of the study indicated that on average, partners played individual games and responded opportunistically to private choices at the expense of household choices. This is important for making progress on the question of intra-household resource allocations and gender conflicts in inefficient 
households.

\section{Conclusion}

The review of literature on intrahousehold allocation describes a set of individual strategies that household agents use to by-pass intrahousehold negotiations and to secure private resources for personal consumption. In many of the instances where inefficiencies have been identified in the data, a possible immediate cause is individual behaviour aimed at securing personal resources and consumption. Even, if they come, at the expense of total resources available to the household. Although, it need not be the case that such strategic behaviour are necessarily the source of inefficiencies, they may well be feeding the flames of suboptimal outcomes in household production systems and that must be pointed out. This paper documents these strategies and suggests a number of avenues for economists. It makes three distinct conclusions based on analysis of the evidence drawn from the numerous experiments: First, the review points out that non-cooperative behaviour of spouses could be a major source of inefficiency and reduced household prosperity. However, under certain conditions, strategic behaviour to secure private savings through the 'practice of income hiding' could be critical to circumventing the web of social norms and gender conflicts that prevent women from seizing new economic opportunities. In otherwords, it is important to understand clearly the context in which noncooperative behaviours induce an increase rather than a waste of household resources. The second set of important conclusions reached by review points to the collective resistance of household agents to economic changes that threaten social norms and gender roles in the developing world. The study chronicles major instances in which individuals have collaborated to stop women and the vulnerable from taking new economic steps that overturn traditional roles. The deep motives of social forces to limit social and economic innovations need to be properly understood, if policy makers are to promote household changes. Third, this review highlights the importance of adopting multicultural disciplines in getting to the bottom of gender conflicts and household inefficiencies. A cross-fertilization of different branches of social science would perhaps provide precise knowledge for understanding the anthropological realities of the context in which intrahousehold allocations are made.

\section{References}

Acosta, M., Van Wessel, M., VanBommel, S., Ampaire, E., Twyman, J., Jassogne, L., ... Fei ndt, P. (2020). What does it mean to make a 'joint' decision? Unpacking intra-household decision making in agriculture: Implications for policy and practice. The Journal of Development Studies, 56(6), 1210-1229. https://doi.org/10.1080/00220388.2019.1650169

Akresh, R., Chen, J. J., \& Moore, C. T. (2012). Productive efficiency and the scope for cooperation in polygynous households. American Journal of Agricultural Economics, 94, 395-401. https://doi.org/10.1093/ajae/aar093

Andersen, S., Bulte, E., Gneezy, U., \& List, J. A. (2008). Do women supply more public goods than men? Preliminary experimental evidence from matrilineal and patriarchal societies. American Economic Review, 98, 376-381. https://doi.org/10.1257/aer.98.2.376

Anderson, S., \& Baland, J. M. (2002). The economics of roscas and intrahousehold resource allocation. Quarterly Journal of Economics, 117, 963-995. https://doi.org/10.1162/003355302760193931

Angelucci, M., De Giorgi, G., Rangel, M. A., \& Rasul, I. (2010). Family networks and school enrolment: Evidence from a randomized social experiment. Journal of Public Economics, 94, 197-221. https://doi.org/10.1016/j.jpubeco.2009.12.002

Antman, F. M. (2015). Gender discrimination in the allocation of migrant household resources. Journal of Population Economics, 28, 565-592. https://doi.org/10.1007/s00148-015-0548-x

Antman, F. M. (2018). Women and migration. In S. L. Averett, L. M. Argys, \& S. D. Hoffman (Eds.), Oxford handbook of women and the economy (pp. 731-747). New York: Oxford University Press. https://doi.org/10.1093/oxfordhb/9780190628963.013.31

Ashraf, N. (2009). Spousal control and intra-household decision-making: An experimental study in the Philippines. American Economic Review, 99, 1245-1277. https://doi.org/10.1257/aer.99.4.1245

Ashraf, N., Field, E., \& Lee, J. (2014). Household bargaining and excess fertility: An experimental study in Zambia. American Economic Review, 104, 2210-2237. https://doi.org/10.1257/aer.104.7.2210

Baland, J. M., \& Ziparo, R. (2018). Intra-household bargaining in poor countries. In S. Anderson, L. Beaman, \& J. P. Platteau (Eds.), Towards gender equity in development (pp. 69-96). Helsinki: United Nations University World Institute for Development Economics Research. https://doi.org/10.1093/oso/9780198829591.003.0004 
Baland, J. M., Bonjean, I., Guirkinger, C., \& Ziparo, R. (2016). The economic consequences of mutual help in extended families. Journal of Development Economics, 123, 38-56. https://doi.org/10.1016/j.jdeveco.2016.07.004

Barr, A., Dekker, M., Janssens, W., Kebede, B., \& Kramer, B. (2019). Cooperation in polygynous households. American Economic Journal. Applied Economics, 11, 266-283. https://doi.org/10.1257/app.20170438

Basset, J. (2004). Women's cotton and the spaces of gender politics in northern cote'd'voire. Gender, Place \& Culture, 9, 351-370. https://doi.org/10.1080/0966369022000024669

Beaman, L., \& Dillon, A. (2012). Do household definitions matter in survey design? Results from a randomized survey experiment in Mali. Journal of Development Economics, 98, 124-135. https://doi.org/10.1016/j.jdeveco.2011.06.005

Becker, G. S. (1981). A treatise on the family. Cambridge: Harvard University Press.

Bergstorm, T. C. (1997). A survey of theories of the family. In M. R. Rosenzweig, \& O. Stark (Eds.), Handbook of population and family economics (Vol. 1A, pp. 21-79). Amsterdam: North-Holland Publishing Company. https://doi.org/10.1016/S1574-003X(97)80019-0

Bergstrom, T., Blume, L., \& Varian, H. (1986). On the private provision of public goods. Journal of Public Economics, 29, 25-49. https://doi.org/10.1016/0047-2727(86)90024-1

Bernhardt, A., Field, E., Pande, R., \& Rigol, N. (2019). Household matters: Revisiting the returns to capital among female microentrepreneurs. American Economic Review: Insights, 1, 141-160. https://doi.org/10.1257/aeri.20180444

Bertrand, M., Mullainathan, S., \& Miller, D. (2003). Public policy and extended families: Evidence from pensions in South Africa. World Bank Economic Review, 17, 27-50. https://doi.org/10.1093/wber/lhg014

Bharat, S. (1994). Alternate family patterns and policies. In M. Desai (Ed.), Enhancing the role of the family as an agency for social and economic development (pp. 72-76). Mumbai: TISS.

Bobonis, G. J. (2009). Is the allocation of resources within the household efficient? New evidence from a randomized experiment. Journal of Political Economy, 117(3), 453-503. https://doi.org/10.1086/600076

Bongaarts, J. (2001). Household size and composition in the developing world in the 1990s. Population Studies, 55(3), 263-279. https://doi.org/10.1080/00324720127697

Borooah, V. K. (2012). Social identity and educational attainment: The role of caste and religion in explaining differences between children in India. Journal of Development Studies, 48, 887-903. https://doi.org/10.1080/00220388.2011.621945

Braaten, R. H. (2014). Land rights and community cooperation: Public goods experiments from Peru. World Development, 61, 127-141. https://doi.org/10.1016/j.worlddev.2014.04.002

Browning, M., Chiappori, P. A., \& Weiss, Y. (2014). Economics of the family. Cambridge: Cambridge University Press.

Caldwell, J. C., Reddy, P. H., \& Caldwell, P. (1984). The determinants of family structure in rural South India. Journal of Marriage and Family, 46, 215-229. https://doi.org/10.2307/351879

Castilla, C. (2015). Trust and reciprocity between spouses in India. American Economic Review, 105, 621-624. https://doi.org/10.1257/aer.p20151117

Castilla, C., \& Walker, T. (2013). Is ignorance bliss? The effect of asymmetric information between spouses on intra-household allocations. American Economic Review, 103, 263-268. https://doi.org/10.1257/aer.103.3.263

Chaudhuri, A. (2011). Sustaining cooperation in laboratory public goods experiments: A selective survey of the literature. Experimental Economics, 14, 47-83. https://doi.org/10.1007/s10683-010-9257-1

Chiappori, P. A. (1992). Collective labor supply and welfare. Journal of Political Economy, 100, 437-467. https://doi.org/10.1086/261825

Chiputwa, B., \& Qaim, M. (2016). Sustainability standards, gender, and nutrition among smallholder farmers in $\begin{array}{lllll}\text { Uganda. The Journal of Development } & \text { Studies, }\end{array}$ https://doi.org/10.1080/00220388.2016.1156090

Clark, G. (1995). Onions are my husband: Survival and accumulation by West African Market women. The University of Chicago Press. https://doi.org/10.7208/chicago/9780226107769.001.0001 
Cochard, F., Couprie, H., \& Hopfensitz, A. (2016). Do spouses cooperate? An experimental investigation. Review of Economics of the Household, 14, 1-26. https://doi.org/10.1007/s11150-014-9276-3

Coffey, D., Khera, R., \& Spears, D. (2016, April). Intergenerational effects of women's status: Evidence from joint Indian households. PAA 2016 Annual Meeting, Washington DC. Retrieved from https://paa.confex.com/paa/2016/meetingapp.cgi/Paper/6434

Cornwall, A. (2016). Women's empowerment: What works?. Journal of International Development, 28(3), 342-359. https://doi.org/10.1002/jid.3210

Cox, D., \& Fafchamps, M. (2007). Extended family and kinship networks: Economic insights and evolutionary directions. In T. P. Schultz, \& J. A. Strauss (Eds.), Handbook of development economics (Vol. 4, pp. 3711-3784). Amsterdam: Elsevier. https://doi.org/10.1016/S1573-4471(07)04058-2

D'cruz, P., \& Bharat, S. (2001). Beyond joint and nuclear: The Indian family revisited. Journal of Comparative Family Studies, 32, 167-194. https://doi.org/10.3138/jcfs.32.2.167

Damon, A. L., \& McCarthy, A. S. (2019). Partnerships and production: Agriculture and polygyny in Tanzanian households. Agricultural Economics, 50, 527-542. https://doi.org/10.1111/agec.12507

De Brauw, A., Gilligan, D., Hoddinott, J., \& Roy, S. (2014). The impact of Bolsa Família on women's decision-making power. World Development, 59, 487-504. https://doi.org/10.1016/j.worlddev.2013.02.003

De Weerdt, J., Genicot, G., \& Mesnard, A. (2019). Asymmetry of information within family networks. Journal of Human Resources, 54, 225-254. https://doi.org/10.3368/jhr.54.1.0616.8023R1

Debnath, S. (2015). The impact of household structure on female autonomy in developing countries. Journal of Development Studies, 51, 485-502. https://doi.org/10.1080/00220388.2014.983909

Dercon, S., \& Krishnan, P. (2000). In sickness and in health: Risk sharing within households in rural Ethiopia. Journal of Political Economy, 108, 688-727. https://doi.org/10.1086/316098

Deshpande, A. (2017). Affirmative action in India. In E. Kennedy-Dubourdieu (Ed.), Race and inequality: World perspectives on affirmative action (pp. 63-76). London: Taylor and Francis.

Dhanaraj, S., \& Mahambare, V. (2019). Family structure, education and women's employment in rural India. World Development, 115, 17-29. https://doi.org/10.1016/j.worlddev.2018.11.004

Doss, C. R., \& Quisumbing, A. R. (2020). Understanding rural household behaviour: Beyond boserup and Becker. Agricultural Economics, 51(1), 47-58. https://doi.org/10.1111/agec.12540

Duflo, E. (2012). Women empowerment and economic development. Journal of Economic Literature, 50, 1051-1079. https://doi.org/10.1257/jel.50.4.1051

Eder, J. (2006). Gender relations and household economic planning in the rural Philippines. Journal of Southeast Asian Studies, 37, 397-413. https://doi.org/10.1017/S0022463406000701

Falen, D. J. (2011). Power and Paradox: Authority, Insecurity, and Creativity in Fon Gender relations. Trenton, NJ. African World Press.

Fapohuda, E. (1988). The non-pooling household, a challenge to theory.

Foster, A. D., \& Rosenzweig, M. R. (2002). Household division and rural economic growth. Review of Economic Studies, 69, 839-869. https://doi.org/10.1111/1467-937X.00228

Gitter, S. R., \& Barham, B. L. (2008). Women's power, conditional cash transfers, and schooling in Nicaragua. World Bank Economic Review, 22, 271-290. https://doi.org/10.1093/wber/lhn006

Green, D. P., Wilke, A. M., \& Cooper, J. (2020). Countering violence against women by encouraging disclosure: A mass media experiment in rural Uganda. Comparative Political Studies, 53(14), 2283-2320. https://doi.org/10.1177/0010414020912275

Guirkinger, C., Platteau, J. P., \& Goetghebuer, T. (2015). Productive inefficiency in extended agricultural households: Evidence from Mali. Journal of Development Economics, 116, 17-27. https://doi.org/10.1016/j.jdeveco.2015.03.003

Hanmer, L., \& Klugman, J. (2016). Exploring women's agency and empowerment in developing countries: Where do we stand?. Feminist Economics, 22(1), 237-263. https://doi.org/10.1080/13545701.2015.1091087 
Harris-Fry, H., Shrestha, N., Costello, A., \& Saville, N. M. (2017). Determinants of intra-household food allocation between adults in South Asia: A systematic review. International Journal for Equity in Health, 16, 107. https://doi.org/10.1186/s12939-017-0603-1

Heath, R., Hidrobo, M., \& Roy, S. (2020). Cash transfers, polygamy, and intimate partner violence: Experimental evidence from Mali. Journal of Development Economics, $143,102410$. https://doi.org/10.1016/j.jdeveco.2019.102410

Hidrobo, M., Hoel, J., \& Wilson, K. (2020). Efficiency and status in polygynous pastoralist households. Journal of Development Studies, 1-17.

Hoff, K., Kshetramade, M., \& Fehr, E. (2011). Caste and punishment: The legacy of caste culture in norm enforcement. Economic Journal, 121, F449-F475. https://doi.org/10.1111/j.1468-0297.2011.02476.x

Hoodfar, H. (1988). Household bargaining in Cairo. In D. Dwyer, \& J. Bruce (Eds.), A home divided, women and Income in the 3rd world (pp. 120-142). Standford University Press.

Iversen, V., Jackson, C., Kebede, B., Munro, A., \& Verschoor, A. (2011). Do spouses realise cooperative gains? Experimental evidence from rural Uganda. World Development, 39, 569-578. https://doi.org/10.1016/j.worlddev.2010.09.011

Jakiela, P., \& Ozier, O. (2016). Does Africa need a rotten kin theorem? Experimental evidence from village economies. Review of Economic Studies, 83, 231-268. https://doi.org/10.1093/restud/rdv033

Jeffery, P., \& Jeffery, R. (2018). Don't marry me to a plowman!: Women's everyday lives in rural north India. New York: Westview Press. https://doi.org/10.4324/9780429500916

Joseph, T., Nyarko, Y., \& Wang, S. Y. (2018). Asymmetric information and remittances: Evidence from matched administrative data. American Economic Journal, Applied Economics, 10(2), 58-100. https://doi.org/10.1257/app.20160150

Kambhampati, U. S., \& Rajan, R. (2008). The 'nowhere' children: Patriarchy and the role of girls in India's rural economy. Journal of Development Studies, 44, 1309-1341. https://doi.org/10.1080/00220380802264978

Kazianga, H., \& Wahhaj, Z. (2013). Gender, social norms, and household production in Burkina Faso. Economic Development and Cultural Change, 61, 539-576. https://doi.org/10.1086/669258

Kebede, B., Tarazona, M., Munro, A., \& Verschoor, A. (2014). Intra-household efficiency: An experimental study from Ethiopia. Journal of African Economies, 23, 105-150. https://doi.org/10.1093/jae/ejt019

Khatri, A. (1975). The adaptive extended family in India today. Journal of Marriage and the Family, 37, 633-642. https://doi.org/10.2307/350528

LaFave, D., \& Thomas, D. (2017). Extended families and child well-being. Journal of Development Economics, 126, 52-65. https://doi.org/10.1016/j.jdeveco.2016.11.006

Lecoutere, E., \& Jassogne, L. (2019). Fairness and efficiency in smallholder farming: The relation with intrahousehold decision-making. The Journal of Development Studies, 55(1), 57-82. https://doi.org/10.1080/00220388.2017.1400014

Lentz, E. C. (2018). Complicating narratives of women's food and nutrition insecurity: Domestic violence in rural Bangladesh. World Development, 104, 271-280. https://doi.org/10.1016/j.worlddev.2017.11.019

Mani, A. (2020). Mine, yours or ours? The efficiency of household investment decisions: An experimental approach. World Bank Economic Review, 34, 575-596. https://doi.org/10.1093/wber/lhz043

McCarthy, N., \& Kilic, T. (2017). Stronger together: Intrahousehold cooperation and household welfare in Malawi. Policy Research Working Paper, WPS 8043. Washington, DC: World Bank. https://doi.org/10.1596/1813-9450-8043

Medora, N. P. (2007). Strengths and challenges in the Indian family. Marriage \& Family Review, 41, 165-193. https://doi.org/10.1300/J002v41n01_09

Millán, T. M., Barham, T., Macours, K., Maluccio, J. A., \& Stampini, M. (2019). Long-term impacts of conditional cash transfers: Review of the evidence. World Bank Research Observer, 34, 119-159. https://doi.org/10.1093/wbro/lky005

Mookerjee, S. (2019). Gender-neutral inheritance laws, family structure, and women's status in India. World Bank Economic Review, 33, 498-515. https://doi.org/10.1093/wber/lhx004 
Munro, A. (2018). Intra-household experiments: A survey. Journal of Economic Surveys, 32(1), 134-175. https://doi.org/10.1111/joes.12196

Munro, A., Kebede, B., Tarazona, M., \& Verschoor, A. (2019). The lion's share: An experimental analysis of polygamy in Northern Nigeria. Economic Development and Cultural Change, 67, 833-861. https://doi.org/10.1086/700102

Munro, A., Kebede, B., Tarazona-Gomez, M., \& Verschoor, A. (2014). Autonomy and efficiency. An experiment on household decisions in two regions of India. Journal of the Japanese and International Economies, 33, 114-133. https://doi.org/10.1016/j.jjie.2013.10.009

Nberrao, N. (2012). Breadwinners and homemakers: Migration and changing conjugal expectations in rural Bangladesh. Journal of Development Studies, 48(1), 26-40. https://doi.org/10.1080/00220388.2011.629648

Paulme, D. (1960). Structures, Sociales traditionnelles, En Afrique Noire. Cahiers d' etudes africanines. https://doi.org/10.3406/cea.1960.2936

Pecenka, C. J., \& Kundhlande, G. (2013). Theft in South Africa: An experiment to examine the influence of racial identity and inequality. Journal of Development Studies, 49, 737-753. https://doi.org/10.1080/00220388.2012.754431

Peterman, A., Behrman, J., \& Quimbing, A. (2011). A review of empirical evidence on Gender differences in non-land agricultural Input technology and service in developing countries. ESA Working papers, 289010, Food and Adgriculture Organisation of the Uninted Nations. Agricultural Development Economics Division (ESA).

Porter, M., \& Adams, A. (2016). For love or reward? Characterising preferences for giving to parents in an experimental setting. Economic Journal, 126, 2424-2445. https://doi.org/10.1111/ecoj.12248

Rajadhyaksha, U., \& Smita, S. (2004). Tracing a timeline for work and family research in India. Economic and Political Weekly, 39(17), 1674-1680.

Ram, M., \& Wong, R. (1994). Covariates of household extension in rural India: Change over time. Journal of Marriage and the Family, 56(4), 853-864. https://doi.org/10.2307/353598

Rangel, M., \& Thomas, D. (2019). Decision-making in complex households. NBER Working Paper No w26511. National Bureau of Economic Research. https://doi.org/10.3386/w26511

Rosenzweig, M. R., \& Wolpin, K. I. (1985). Specific experience, household structure, and intergenerational transfers: Farm family land and labor arrangements in developing countries. Quarterly Journal of Economics, 100S, 961-987. https://doi.org/10.1093/qje/100.Supplement.961

Rossi, P. (2019). Strategic choices in polygamous households: Theory and evidence from Senegal. Review of Economic Studies, 86, 1332-1370. https://doi.org/10.1093/restud/rdy052

Salifu, G. A. N. (2019b). The political economy dynamics of rural household income diversification: Review of the international literature. Research in World Economy, 10(3), 10-34. https://doi.org/10.5430/rwe.v10n3p273

Salifu, G. A. N. (2020). Political Economy Analysis of Income Diversification Activities of Rural Households and Food Security: A Case Study of Yendi and Nanumba North Districts of the Northern Region of Ghana. Unpublished Doctoral Thesis, Department of Agricultural Economics and Agribusiness, University of Ghana. https://doi.org/10.11114/aef.v6i5.4405

Salifu, G. A. N. (2021). Covid-19's impact on the international political economy of food security. Research in World Economy, 12(1), 10-34. https://doi.org/10.5430/rwe.v12n1p379

Salifu, G. A. N. (2021). Picking the right arrow for the target: modelling economic impact of agribusiness entreprenuership and rural unemployment in Sub-Saharan Africa. Business and Management Research, 10(1), 10-34. https://doi.org/10.5430/bmr.v10n1p18

Salifu, G. A. N., \& Anaman, K. A. (2019a). Political economy analysis of income diversification of rural households in the northern region of Ghana. Applied Economics and Finance, 6(5), 10-34. https://doi.org/10.11114/aef.v6i5.4405

Scott, M. E., \& Karberg, E. (2016). Measuring children's care arrangements and their educational andhealth outcomes internationally. Global Social Welfare, 3, 75-89. https://doi.org/10.1007/s40609-016-0059-z

Sharma, U. (1980). Women, work and property in North West India. London: Tavistock Publications.

Speizer, I. S., Lance, P., Verma, R., \& Benson, A. (2015). Descriptive study of the role of household type and household composition on women's reproductive health outcomes in urban Uttar Pradesh, India. Reproductive Health, 12(1), 4. https://doi.org/10.1186/1742-4755-12-4 
Strauss, J., \& Thomas, D. (1995). Human resources: Empirical modelling of household and family decisions. In J. Behrman, \& T. N. Srinivasan (Eds.), Handbook of development economics (Vol. 3, pp. 1883-2023). Amsterdam: Elsevier. https://doi.org/10.1016/S1573-4471(05)80006-3

Uberoi, P. (1994). Family, kinship and marriage in India. New Delhi: Oxford University Press.

Udry, C. (1996). Gender, agricultural production, and the theory of the household. Journal of Political Economy, 104, 1010-1046. https://doi.org/10.1086/262050

Voss, T. (2005). Game theoretical perspectives on the emergence of social norms. In M. Hechter, \& K. Dopp (Eds.), Social norms chapter 4 (pp, 105-136). New York, Rusell Sage.

Ziparo, R. (2014). Why do spouses communicate. Love or Interest?: a model and some evidence from Cameroon. Mimeo.

\section{Copyrights}

Copyright for this article is retained by the author(s), with first publication rights granted to the journal.

This is an open-access article distributed under the terms and conditions of the Creative Commons Attribution license (http://creativecommons.org/licenses/by/4.0/). 